\title{
Bilateral vertebral artery dissection, agenesis of both ICAs, and connective tissue aberrations
}

\section{Figure 1 MRI with time-of-flight angiography shows bilateral internal carotid artery agenesis, vertebral artery dissections, and ischemias in both middle artery territories}

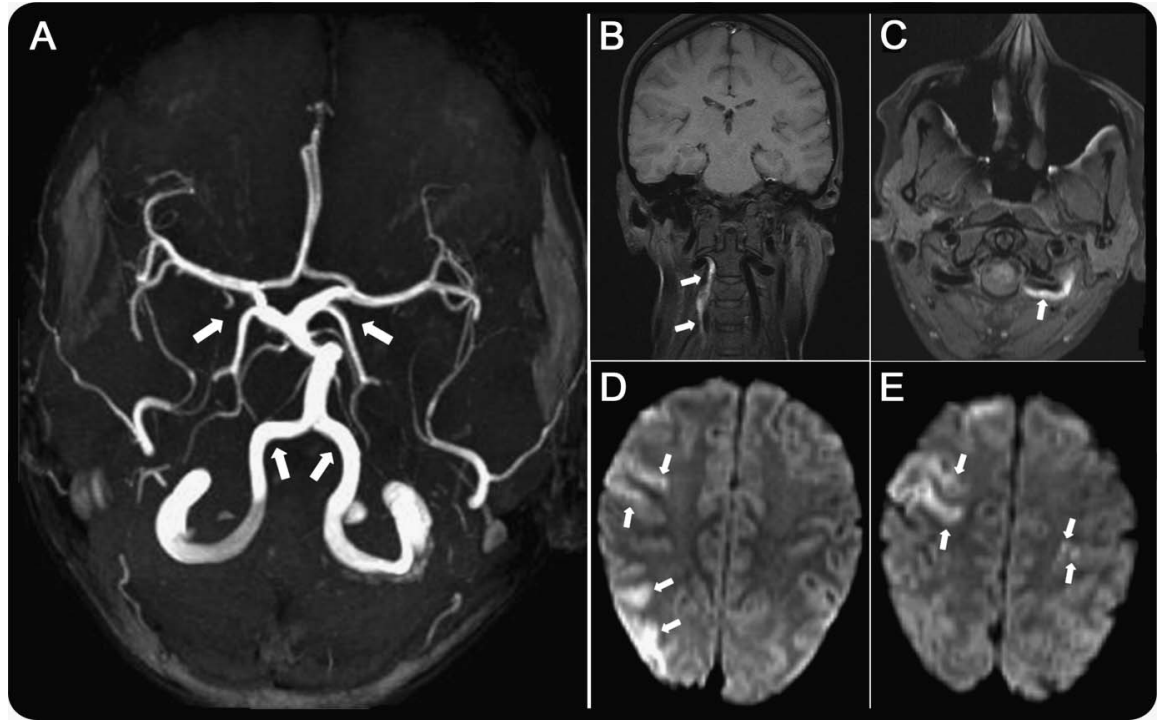

Time-of-flight MRI angiography shows absence of both internal carotid arteries ( $\mathrm{A}$, upper arrows) and enlarged vertebral arteries (VAs) providing compensatory blood supply (lower arrows). It further reveals bilateral VA dissections, with cervical dissection in segment V2 on the right (B) and in segment V3 on the left (C). Ischemic lesions in both middle artery territories are visible (D, E).

A 35-year-old woman presented with acute signs of stroke (appendix e-1 on the Neurology ${ }^{\circledR}$ Web site at www. neurology.org). After initial CT with angiography, MRI with time-of-flight angiography confirmed agenesis of both internal carotid arteries (ICAs; figure 1A). It revealed bilateral vertebral artery (VA) dissections and ischemias in both middle artery territories (figure 1, A-E). Skin biopsy microscopy (figure 2) was consistent with ultrastructural

Figure 2 Electron microscopy of the skin biopsy shows evidence of ultrastructural connective tissue aberrations
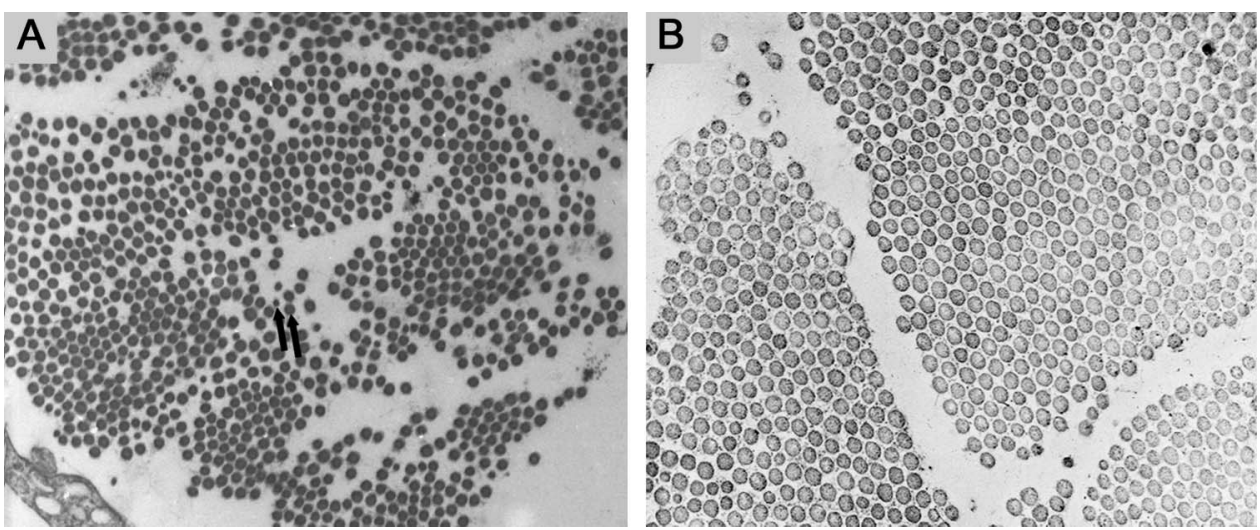

Electron microscopy of the skin biopsy (A, magnification $\times 35,000$ ) shows loosely packed collagen bundles with caliber variability of fibrils (arrows) consistent with an ultrastructural connective tissue syndrome. (B) Historical control for comparison purposes. 
connective tissue disease (uCTD), for which no further evidence was found apart from mild hypermobility of the finger joints. The underlying uCTD with structural instability of the arterial walls and the increased blood flow in the vertebrobasilar circulation due to the bilateral ICA agenesis may have promoted VA dissection.

Christina M. Lill, MD, Kristin Günther-Kunkel, MD, Heinrich Hoch, MD, Friedemann Paul, MD, Caspar Grond-Ginsbach, PhD, Ingrid Hausser, PhD, Frauke Zipp, MD

From the Rhine Main Neuroscience Network (rmn2), Johannes Gutenberg University Center, Department of Neurology (C.M.L., F.Z.), Mainz; Neuropsychiatric Genetics Group, Department of Vertebrate Genomics, Max Planck Institute for Molecular Genetics (C.M.L.), Berlin; Institute for Neuroradiology, Helios-Klinikum Berlin-Buch (K.G.-K., H.H.), Berlin; Charité-University Medicine Berlin (F.P.), Berlin; Department of Neurology (C.G.-G.), the Department of Dermatology and Electron Microscopy Core Facility (I.H.), University of Heidelberg, Heidelberg, Germany.

Author contributions: Study concept and design: Drs. Lill and Zipp. Acquisition of data, analysis and interpretation: Drs. Lill, GüntherKunkel, Hoch, Paul, Grond-Ginsbach, Hausser, and Zipp. Writing of first manuscript draft: Dr. Lill. Critical revision of the manuscript: Drs. Hoch, Hausser, and Zipp.

Study funding: No targeted funding reported.

Disclosure: The authors report no disclosures relevant to the manuscript. Go to Neurology.org for full disclosures.

Correspondence to Dr. Zipp: frauke.zipp@unimedizin-mainz.de

\section{NeuroImages Are Free at www.neurology.org!}

All Neurology ${ }^{\circledR}$ NeuroImages can now be freely accessed on the Neurology Web site. See them at www.neurology.org, where you can also sign up for journal email alerts and check out other online features, including the Resident \& Fellow section, Neurology: Clinical Practice, and the weekly Neurology Podcasts. 


\section{Neurology}

\section{Bilateral vertebral artery dissection, agenesis of both ICAs, and connective tissue aberrations}

Christina M. Lill, Kristin Günther-Kunkel, Heinrich Hoch, et al.

Neurology 2013;80;1442-1443

DOI 10.1212/WNL.0b013e31828c2f8e

\section{This information is current as of April 8, 2013}

Updated Information \& Services

Supplementary Material

Subspecialty Collections

Permissions \& Licensing

Reprints including high resolution figures, can be found at:

http://n.neurology.org/content/80/15/1442.full

Supplementary material can be found at: http://n.neurology.org/content/suppl/2013/04/07/80.15.1442.DC1

This article, along with others on similar topics, appears in the following collection(s):

All Cerebrovascular disease/Stroke

http://n.neurology.org/cgi/collection/all_cerebrovascular_disease_strok

Carotid artery dissection

http://n.neurology.org/cgi/collection/carotid_artery_dissection

MRI

http://n.neurology.org/cgi/collection/mri

Stroke in young adults

http://n.neurology.org/cgi/collection/stroke_in_young_adults

Information about reproducing this article in parts (figures,tables) or in its entirety can be found online at:

http://www.neurology.org/about/about_the_journal\#permissions

Information about ordering reprints can be found online:

http://n.neurology.org/subscribers/advertise

Neurology ${ }^{\circledR}$ is the official journal of the American Academy of Neurology. Published continuously since 1951, it is now a weekly with 48 issues per year. Copyright @ 2013 American Academy of Neurology. All rights reserved. Print ISSN: 0028-3878. Online ISSN: 1526-632X.

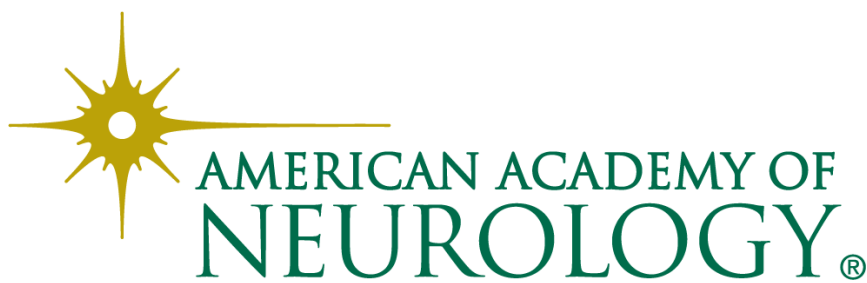

